\title{
Chapter 29 \\ The Role of Pension Policies in Preventing Old-Age Exclusion
}

\author{
Jim Ogg
}

\subsection{Introduction}

Pension systems are a major component in reducing social exclusion in older-age. The introduction of pensions throughout many countries during the twentieth century was primarily a measure designed to reduce poverty in old-age. Without pensions, few options were available for older people to secure an income, and an absence of income is one of the main determinants of social exclusion in later life (Walsh et al. 2017). Many, if not most of the jobs associated with industrial or agricultural economies of the early twentieth century were manual and demanding and, in the absence of developed retirement systems, most older people worked until they were physically unable to continue. Levels of income in paid employment over the life course were mostly insufficient to enable saving for retirement. In the absence of pensions, intergenerational family transfers (including cohabitation), mainly by children to their ageing parents, were the most common form of ensuring that basic needs in old-age were met.

As state pension systems were introduced and with universal coverage in most industrialised societies, retirement became an institutional period of the life course, defined as an absence of paid work and the receipt of a guaranteed income (Kohli 2007). To be sure, most pensions were well below the level of income workers had received before retirement. For example, although pensions had become almost universal in the United Kingdom (UK) by the 1950s, their level was low compared to previous wages and most retirees did not have enough pension income to participate fully in social life. Writing at the time, Peter Townsend in his study of the family life of older people noted that:

\footnotetext{
J. Ogg $(\square)$

Caisse Nationale d'assurance Vieillesse, Paris, France

e-mail: jim.ogg@cnav.fr
} 
If the pension had ensured a more comfortable standard of life men might not have had the depressing sense of having become "poor relations" and might have held their heads higher among their children (Townsend 1957, p.147).

Nevertheless, as the value of pensions continued to rise throughout the 1960s and 1970s, the gains in terms of enabling older people to participate fully in the social and civic life of their communities were numerous. Workers were able to look forward to a planned and secure retirement, in the knowledge that they would receive a guaranteed income. Pensions that were calculated on the basis of "defined benefits" became widespread and workers mostly knew in advance the value of their pension since the benefits accrued were linked to earnings and employment careers and the level of future pension was pre-defined and guaranteed. Occupational pensions administered by employers also developed alongside the "first pillar" state pensions. With income security in old-age, residential independence became the norm, as witnessed by the large increase throughout western Europe in the number of older one-person households during the 1960s. Older people relied less and less on their kin for their basic needs. A regular income in old-age also enabled retirees to participate in leisure and cultural activities, thereby reducing significantly the risk of social exclusion. This led to what some commentators have referred to as a "golden age" in the history of pensions. In the UK, the majority of early baby boomers (individuals born in the late 1940s and early 1950s) who began to enter retirement at the beginning of the twenty-first century and who were living in a couple, received total pension incomes at the same or higher level than the incomes they received when they were working (Chandler and Tetlow 2014). In such situations, social exclusion in old-age was significantly reduced and where it did exist, factors other than income were determinant.

As pension systems developed and coverage extended to all workers, specific redistributive elements were also incorporated to protect older people from poverty, either by ensuring a minimum level of pension income for retirees whose contributions would not normally allow an adequate pension, or by providing a basic income to individuals who had never worked. Survivor pensions also became common, whereby the loss of income caused by the death of a spouse with pension rights (usually a man) was compensated by transferring a proportion of the pension to the remaining spouse. These measures were, and still are, important components of pension systems and they are discussed in more detail below.

\subsection{The Contribution of Pensions to Income Adequacy}

Clearly, pensions have played a major role in the reduction of poverty (Jeffreys 1989), although the accumulation of assets is also an important factor. Recent figures relating to Europe show that from 2008 to 2016, the number of people aged 65 and over at risk of poverty or social exclusion in the European Union (EU) decreased by around 1.9 million (OECD 2018). Moreover, pensions mitigate against material 
deprivation, defined as "the inability to possess the goods and services and/or engage in activities that are ordinary in the society or that are socially perceived as 'necessities;" (Fusco et al. 2010, p.7) [see also Ogg and Myck, Chap. 2, SumilLaanemaa et al., Chap. 3, and Myck et al., Chap. 24, this volume for a discussion and empirical analysis of material deprivation in later life]. Although it is difficult to quantify the impact that pensions have on reducing exclusion and on living standards in general, one measure is the theoretical replacement rate (TRR), an indicator of the level of pension income after retirement as a percentage of individual earnings at the moment a pension is claimed (or as an average of earnings). Figure 29.1 shows the TRR in a selected number of European and near-neighbour countries. In 2017, on average in the European Union (28 countries), the replacement ratio of pensions was 0.58 , illustrating their important role in the provision of adequate incomes in old-age.

This important role that pensions play in providing income in old-age conceals gender differences, more commonly known as the gender pension gap that represents the difference between the average pre-tax income received as a pension by women and compared to men. As far as pensions in the EU 28 are concerned, the gender pension gap ranges from 1.8 to $48.7 \%$, with an average of $37.2 \%$ for individuals in the age group 65-79 years (OECD 2018, p.69). Recent trends suggest that "while slight decreases in gender gaps in pensions have been observed in the $\mathrm{EU}$ on average since the [global financial] crisis, the gaps remain almost stable in many countries, including in those where it is highest" (OECD 2018, p.70).



Fig. 29.1 Aggregate replacement ratio for pensions (excluding other social benefits)

Source: Eurostat (last update 17 July 2019). The indicator is defined as the ratio of the median individual gross pensions of 65-74 age category relative to median individual gross earnings of 50-59 age category, excluding other social benefits. The indicator is based on the EU-SILC (statistics on income, social inclusion and living conditions) 
A longer life expectancy for women has consequences for income in later life, especially bearing in mind higher rates of poverty among older women compared to men. More than $20 \%$ of women aged 65 years and above are at risk of poverty or social exclusion in the EU, compared to $15 \%$ of men in the same age group (OECD 2018).

In addition to gender inequalities, other sectors of the population are disadvantaged in terms of access to pensions. International migration and the administrative barriers in harmonising a working career undertaken in two or more countries places specific risks of exclusion on migrant workers. In the EU, mobile citizens are entitled to a pension from each Member State in which they were insured. However, accessibility rules differ between countries as, for example, when a condition of residence is required to obtain a pension. Also, some countries allow access to their pension systems for regular migrants working in sectors such as agricultural work, construction work or social care, whereas in other countries this is not the case. For these workers, who in retirement return to their home country, the "portability" of the rights they have accrued and the ability to access them once in their home country poses substantial risks for exclusion in old-age. Inequalities in access to pensions also exist for individuals who have not been able to fulfil the eligibility requirements for a pension due to career gaps because of disability and poor health. Since income in old-age is mainly provided through pensions, and pensions are dependent on paid work over the life course, disabled individuals who cannot secure full-time paid work over the life course are exposed to specific risks.

Although the contribution that pensions have made to minimising social exclusion is beyond doubt, there have been a number of important systemic changes to the way that pensions are calculated and managed. Central to these changes is the shift away from the public sector and employers' responsibility to ensure adequate pensions, to the individualisation of retirement income responsibility. Through tax incentives, policies have been introduced encouraging individuals to make personal provision for their pensions, mostly through financial markets managed by intermediaries (banks, asset management companies etc.). Ageing populations have particular consequences for pension systems, particularly those which rely upon pay-as-you-go systems, whereby current contributions finance current pension expenditure. Again, shifts towards defined contributions within public first pillar pension systems place the responsibility for accumulating pension rights firmly on the individual. As Krekula and Vickerstaff (2020) note, "this narrative of individual responsibility replaces an earlier sense of moral economy in which the reproduction of labour meant that the young and old had privileged positions in society based on their future and past contributions" (2020, p. 38). Under these circumstances, the very notion of retirement is brought into question (Phillipson 2019) since certain sectors of the population are obliged to continue working to secure an adequate income in old-age. Moreover, changing labour markets and economic crises often undermine the ability of older individuals to find paid work or lead to a reduction in the value of their pensions due to the bad performance of pension funds and investments. In addition, financial crises, past and ongoing, adversely affect women since they are more likely than men to be employed in the temporary, low-skilled and 
part-time jobs that result from economic downturns. The risks of social exclusion in the face of these transformations are spread unequally throughout society, and many pension systems are grappling with the problem of squaring the circle of sustainability and equity. In the following section, we examine three major challenges that pension systems face if they are to continue to be one of the main mechanisms in preventing exclusion in old-age: financial sustainability; pensions and global finance; and creating stable labour markets.

\subsection{Challenges for Pension Systems}

\subsubsection{Financial Sustainability}

Faced with ageing populations and increased life expectancy, structural changes to pension systems have been, and continue to be, necessary in order to ensure their financial sustainability. Three parameters that are common to all pension systems can be adjusted. First, the duration of contributions over the working life that are needed in order to receive a full pension can be increased. Most countries have adopted this measure as well as switching to (or introducing) a defined contribution system whereby the level of contributions and not the final benefit, is pre-defined. Moreover, the amount of pension that is finally paid depends not only on the duration of contributions, but also on the return of investments made by the pension scheme. In this way, building-up a pension can be likened to a savings scheme in which the final amount paid out depends upon how much is paid in and how well or badly the savings have performed in the financial market. Defined contribution pension schemes (whether public, occupational or private), and the increased duration of contributions which is a feature of them, clearly have consequences for economic exclusion in later life. Since it is necessary to work longer in order to secure an adequate pension, many individuals who cannot work through illness, disability or because of caring responsibilities within the family, together with those who cannot find work, are exposed to a heightened risk of entering older-age without an adequate level of income. Protective measures for these vulnerable groups are discussed in the next main section.

The second parameter of adjustment to pension systems which aims to maintain financial sustainability is the raising of the minimum age of pension eligibility. Again, most European countries have adopted this measure (with some, notably Poland, oscillating between increasing and decreasing the minimum state pension age according to the political ideology of governments in office). As with the shift from defined contribution pension schemes, the working life is extended and certain groups are exposed to the risk of economic exclusion.

The third parameter of reform consists of reducing the value of a pension. Although extending the working life and linking pensions to life expectancy also means that the total value of pensions paid out is lower than it would have been in 
the absence of these reforms, it is also possible to reduce the value of individual pensions. Politically unpopular, most governments avoid this adjustment, although it was one made by the Greek government following the 2008 global financial crisis (Tinio and Lyberaki 2012). An alternative to cutting the total amount of pension paid is to make changes to the indexation of pensions (mostly from wages to prices). For example, in 2017 in Australia, a change in the indexation of pensions to prices instead of average male weekly earnings resulted in lower pensions for 330,000 retirees (Brooke 2020).

\subsubsection{Pensions and Global Finance}

Coupled with the shift to defined benefit contributions and the individualisation of pension income responsibility through the growth of occupational and private pensions is the increasing role of globalised financial markets in pension systems. Pension systems based on long-term savings schemes invested in financial markets gained world-wide popularity from the 1980s (notably in the case of Chile). In Europe, "several countries, including Sweden and some new Member States such as Bulgaria, Estonia, Croatia, Latvia, Lithuania, Hungary, Poland and Slovakia, have switched part of their public pension schemes into (quasi-) mandatory private funded schemes" (European Commission 2018, p.51). As with any financial investment, significant risks are borne in the management of pension funds and the total value of a pension is determined by the performance of the funds (and how they have been managed). Following the 2008 global financial crisis, the value of pensions was literally wiped out in some countries, notably in Greece but also for some pension funds in the United States of America: "The 2008 economic crisis wreaked havoc on the value of older Americans" individual retirement resources. The value of defined contribution plan balances shrunk as the stock market dropped, equity in housing plummeted, and many had to tap into retirement savings in pre-retirement years to make ends meet" (Street and Ní Léime 2020).

Since the 2008 economic crisis, European occupational pension funds "continue to be negatively affected by the persistent low interest rate environment" (European Insurance and Occupational Pensions Authority 2019, p.34). Many countries have legislated to tighten up investment risk strategies, particularly in relation to supplementary pensions (occupational and private). In 2019, the European Parliament and EU member states reached an agreement on the proposal for a pan-European personal pension product (PEPP), a voluntary scheme for saving for retirement with "strong consumer protection" (European Commission 2019). Within individual countries, protection measures usually take the form of an overseeing regulatory body, as is the case in Ireland since 2018: if a pension fund is in deficit, a financial proposal must be submitted to the Pensions Authority within 6 months.

Hassel and Wi $\beta$ (2019) point out that the global financial crisis has led to "a reassessment of the role of pre-funded private pensions as a complementary, rather than a superior, source of old-age income" (p.1). They suggest that collective 
occupational schemes administered by social partners may be one solution to counter the trend of treating pension funds in the same way as any investment strategy. Nevertheless, risks will always be a component of pension funds with new and perhaps unforeseen risks on the horizon. A recent article in the Financial Times, for example, stated that "fourteen of the UK's biggest pension funds have been warned by lawyers they risk legal action if they fail to consider the effects of climate change on their portfolios" (Financial Times, 13 August 2018).

Controlling the financial management of pension funds may go some way to protecting the future value of total pension income. However, with the increasing individualisation of pension income responsibility, many governments are placing the onus on individuals to devise and choose their own investment strategies and to be accountable for the gains and losses. The assumption is that given the "right" information, individuals are able to make informed choices regarding the financial products on offer with regard to a future pension. However, this assumption is problematic. Kaifala et al. (2019) question the way in which financial experts and accountants treat the key dimensions of pensions, such as their predictability and stability and the way in which information is communicated to clients. Also, the high degree of financial literacy needed to make informed investment choices for future pension income excludes large sectors of the population who do not have such skills.

\subsubsection{Creating Stable Labour Markets}

Pensions are built up through paid work, but in recent years labour markets have been characterised by an increase in precarious and low-paid jobs that fail to allow the work-force to build up sufficient contributions for their pensions. For example, "during the financial crisis of 2008-2013, Finland's proportion of precarious work increased to 13\%, surpassing 1990s recession levels" (Salonen et al. 2020). The rise in short-term contracts and part-time jobs affects particularly young adults who enter the labour market for the first time and older adults who seek to remain in it. Moreover, many, if not most, of the jobs that are insecure are low-paid and entail low-quality work. Working conditions are often harsh and older workers commonly lack skills that would enable them to diversify or are quite simply physically not able to undertake the jobs on offer. Improving the quality of working conditions is therefore an important component of safeguarding adequate pension income.

Retaining older workers in the labour force also requires significant investment in training and the acquisition of new skills. Older workers will need to keep up with technology advances, introduced into their workplace, especially as human labour is replaced by automation. Although there are examples of good practice in the training of older workers, ageism means that they receive less training than younger workers (Krekula 2018) and they are often excluded from new technology training. 


\subsection{Protective Measures Against Exclusion in Pension Systems}

The challenges to pension systems described above mean that it will be crucial in the coming years to ensure that "first pillar" pension schemes retain a redistributive element that protects the most vulnerable sectors of society in the event of not being able to build up sufficient sources of income in old-age. In some countries, a minimum guaranteed pension exists for individuals with no or low financial resources although their value can differ substantially from one country to another. For example, in France, the Allocation de solidarité aux personnes âgées (ASPA) is paid by the state National Pension Fund ( $€ 868.20$ per month in 2019) to individuals aged 65 years and above whose contributions are low and who would normally have received a pension lower than the ASPA rate. A "social pension also exists in Bulgaria for people aged 70 years and above when the annual income of a member of their household is less than the guaranteed minimum income established in the country in the previous 12 months...this social monthly pension is 120.98 лв (€62), one-third of the amount that is set as the poverty line (314 лв or €160 for 2017)" (Trifonova and Lillova 2020).

"Top-up" pensions are also important where individuals have had long careers and made full contributions to the pension system, but on account of their low wages would normally receive a low pension. For example, in Austria, although there is no minimum pension, retirees with low earnings-related benefits receive a meanstested top-up (Ausgleichszulage) which in 2017 amounted to $€ 889.84$ per month for a single-person household (Hass et al. 2020).

In many countries, survivor pensions are important in maintaining incomes. Survivor pensions were designed to protect spouses who risked a large fall in income when their husband/wife died. Given the typically greater life expectancy of women over men, the beneficiaries of survivor pensions are mostly women, and this source of income is especially important where no or limited pension rights have been built up. However, in most countries survivor pensions were paid only in the case of marriage or registered partnerships, with common-law spouses being excluded. In some countries, such as Finland, survivor pensions were also designed to protect underage children (who lived with the surviving spouse). With changing family configurations, many survivor pensions are being reformed, and in some countries there is considerable debate over the need to abolish them given that many women have acquired their own pension rights and therefore a survivor pension is not needed. Abolishing survivor pensions outright would undoubtedly place some women at risk of not receiving an adequate income and it will be important for future policy to make pensions more inclusive and adapted to societal transformations.

Pension systems will need to take into account workers in hazardous jobs for whom it is unreasonable to suppose that they should extend their working life in order to secure adequate pension income. Measures are in place in some countries. For example, in Austria, workers in physically demanding jobs for at least 10 of the 20 years immediately preceding the legal retirement age ("heavy labour pension") 
can retire early (OECD 2017). In France, a personal account aimed at preventing the impact of harsh working conditions was introduced in 2016. Since October 2017, the definition of annual thresholds identifies six occupational risk factors. The account allows employees exposed beyond the thresholds to gain points, which can be used to fund either training opportunities to access less arduous jobs, or a reduction in working hours with wage-loss compensation or retiring earlier with a maximum of 2 years earlier than the legal age of retirement. These measures contribute to safeguarding adequate pension income and reducing exclusion in old-age.

\subsection{Conclusion}

Pension systems play a crucial role in preventing social exclusion in later life. As countries address current demographic and economic challenges, it will become increasingly important to ensure that all sectors of society are protected against economic exclusion in old-age. This means addressing issues such as the extended working life and the consequences for individuals excluded from paid work, tackling gender pay gaps throughout a working career, increasing the "portability" of accrued pension rights between countries for migrant workers, and greater recognition of the value of unpaid work through measures that give access to pensions. Future generations of retirees are likely to have more diverse profiles than current generations, with important sectors of the population who will have accumulated periods of inactivity and low pay. The increasing deinstitutionalisation of the life course and the continued spectre of neo-liberal policies based on individual responsibility for the provision of income in older-age pose specific risks to the sustainability of pension systems hitherto built on the premises of intergenerational solidarity and equity. Redistributive measures will continue to be necessary, either being built-in to pension systems or aligned with them. These can be provided by fiscal reforms and the provision of universal basic pensions indexed to the purchasing power of working populations. Given these measures, the risk of economic exclusion in old-age can be significantly reduced, allowing individuals and their families to fully participate in all domains of social life.

\section{Editors' Postscript}

Please note, like other contributions to this book, this chapter was written before the COVID-19 pandemic of 2020. The book's introductory chapter (Chap. 1) and conclusion (Chap. 34) consider some of the key ways in which the pandemic relates to issues concerning social exclusion and ageing. 


\section{References}

Brooke, E. (2020). Australia. In A. Ní Léime, J. Ogg, D. Street, C. Krekula, M. Rašticová, M. Bédiová, \& I. Madero-Cabib (Eds.), Extended working life policies: International gender and health perspectives (pp. 129-139). New York: Springer.

Chandler, D., \& Tetlow, G. (2014). Retirement in the 21st century (IFS report R98). London: Institute of Fiscal Studies.

European Commission. (2018). The 2018 ageing report. Economic \& budgetary projections for the 28 EU Member States (2016-2070). Brussels: European Commission.

European Commission. (2019). Press release: Capital Markets Union: Commission welcomes political agreement on new rules to help consumers save for retirement. https://europa.eu/ rapid/press-release_IP-19-1108_en.htm. Accessed 1 Aug 2019.

European Insurance and Occupational Pensions Authority. (2019). Financial stability (Report June 2019). Luxembourg: Publications Office of the European Union.

Fusco, A., Guio, A.-C., \& Marlier, E. (2010). Income poverty and material deprivation in European countries, theme: Population and social conditions. Collection: Methodologies and working papers, European Union, 2010, Cat. No. KS-RA-10-030-EN-N.

Haas, B., Gstrein, M., \& Bildsteiner, R. (2020). Austria. In A. Ní Léime, J. Ogg, D. Street, C. Krekula, M. Rašticová, M. Bédiová, \& I. Madero-Cabib (Eds.), Extended working life policies: International gender and health perspectives (pp. 141-152). New York: Springer.

Hassel, A., \& Wi $\beta$, T. (2019). The political economy of pension financialisation: Public policy responses to the crisis. Journal of European Public Policy, 26, SI. https://doi.org/10.108 0/13501763.2019.1575455.

Jeffreys, M. (Ed.). (1989). Growing old in the twentieth century. London: Routledge.

Kaifala, G.B., Paisey, C., \& Paisey, N. J. (2019). The UK pensions landscape - A critique of the role of accountants and accounting technologies in the treatment of social and societal risks. Critical Perspectives on Accounting. Available online: https://doi.org/10.1016/j. cpa.2019.06.005. Accessed 4 July 2019.

Kohli, M. (2007). The institutionalization of the life course: Looking back to look ahead. Research in Human Development, 4(3-4), 253-271.

Krekula, C. (2018). Time, precarisation and age normality: On internal job mobility among men in manual work. Ageing \& Society, 39, 2290-2307. https://doi.org/10.1017/ S0144686X1800137X.

Krekula, C., \& Vickerstaff, S. (2020). The 'older worker' and the 'ideal worker': A critical examination of concepts and categorisations in the rhetoric of extending working lives. In A. Ní Léime, J. Ogg, D. Street, C. Krekula, M. Rašticová, M. Bédiová, \& I. MaderoCabib (Eds.), Extended working life policies: International gender and health perspectives (pp. 29-47). New York: Springer.

OECD. (2017). Key policies to promote longer working lives. Various countries. https://www. oecd.org/els/emp_Key\%20policies_Final.pdf. Accessed 3 July 2019.

OECD. (2018). Pensions at a glance 2017. OECD and G20 indicators. Paris: OECD Publishing. https://doi.org/10.1787/pension_glance-2017-en. Accessed 4 Mar 2019.

Phillipson, C. (2019). 'Fuller' or 'extended' working lives? Critical perspectives on changing transitions from work to retirement. Ageing \& Society, 39(3), 629-665.

Salonen, L., Kähäri, A., \& Pietilä, I. (2020). Finland. In A. Ní Léime, J. Ogg, D. Street, C. Krekula, M. Rašticová, M. Bédiová, \& I. Madero-Cabib (Eds.), Extended working life policies: International gender and health perspectives (pp. 251-260). New York: Springer.

Street, D., \& Ní Léime, Á. (2020). Problems and prospects for current policies to extend working lives. In A. Ní Léime, J. Ogg, D. Street, C. Krekula, M. Rašticová, M. Bédiová, \& I. MaderoCabib (Eds.), Extended working life policies: International gender and health perspectives (pp. 85-113). New York: Springer.

Tinio, P., \& Lyberaki, A. (2012). Labour and pensions in the Greek crisis: The microfoundations of disaster cover. Südosteuropa. Zeitschrift für Politik und Gesellschaft., 3, 363-386. 
Townsend, P. (1957). The family life of old people. London: Routledge/Kegan \& Paul.

Trifonova, T., \& Lillova, K. (2020). Bulgaria. In A. Ní Léime, J. Ogg, D. Street, C. Krekula, M. Rašticová, M. Bédiová, \& I. Madero-Cabib (Eds.), Extended working life policies: International gender and health perspectives (pp. 173-182). New York: Springer.

Walsh, K., Scharf, T., \& Keating, N. (2017). Social exclusion of older persons: A scoping review and conceptual framework. European Journal of Ageing, 14, 81-98. https://doi.org/10.1007/ s10433-016.

Open Access This chapter is licensed under the terms of the Creative Commons Attribution 4.0 International License (http://creativecommons.org/licenses/by/4.0/), which permits use, sharing, adaptation, distribution and reproduction in any medium or format, as long as you give appropriate credit to the original author(s) and the source, provide a link to the Creative Commons license and indicate if changes were made.

The images or other third party material in this chapter are included in the chapter's Creative Commons license, unless indicated otherwise in a credit line to the material. If material is not included in the chapter's Creative Commons license and your intended use is not permitted by statutory regulation or exceeds the permitted use, you will need to obtain permission directly from the copyright holder. 